\title{
- A escritura da paixão
}

\section{Edilma Acloli Bomfim}

É doutora em Letras.

Este ensaio foi publicado pela primeira vez em 1996, no número 18 da Revista Leitura, do Programa de Pós-Graduação em Letras da Universidade Federal de Alagoas, em número intitulado A mulher na literatura: texto e con/ texto, organizado por Izabel Brandão (cf. 149-155). 

Quando se fala de amor, desejo e erotismo, é da história da humanidade que se está falando. O homem se apaixona e, pelo estudo do seu desejo, identificam-se as lutas, as conquistas e as interdições que marcaram o caminho da humanidade em busca de exteriorizar o seu desejo mais íntimo. Assim, se se pode dizer que a história do homem também é a da sua repressão, estudar o seu desejo é uma forma de conhecer melhor a sua história.

Assim, entendendo a arte como uma manifestação discursiva do prazer, a leitura do livro de Arriete Vilela - Fantasia e avesso - suscitou a análise de categorias consideradas por nós básicas ao entendimento do texto, de sua formulação interna e conteúdos veiculados. A primeira prende-se à problemática do erotismo e ao consequente tratamento literário que a sexualidade e o prazer recebem na escrita no momento histórico da produção textual; a segunda, à similitude que o projeto de Arriete constrói entre o erotismo e a linguagem poética.

Por ser um fator cultural, as manifestações eróticas apresentam-se como uma questão que depende da época, de seus valores, dos grupos sociais que estabelecem limites ou normas para as realizações amorosas. O confronto entre a "Carne imperfeita e cheia de instintos malsãos" e a "alma cultuada como o oráculo da morada do divino", tão usado por várias tradições religiosas, sobretudo a judaicocristã, colocou o sexo como a encarnação do pecado, cabendo ao espírito o papel de purificador desse corpo/ carne incontrolável..

A cultura ocidental de base judaico-cristã sempre relegou à sexualidade um papel pejorativo e marginal. Aos seres humanos nunca foi permitido o exercício de sua eroticidade e, consequentemente, manifestá-la era considerado uma violência que escapava ao domínio do sagrado.

Curiosamente, em Fantasia e avesso há todo um périplo de andanças, idas e retornos em busca do amor libertado. A partida já é um instante de assédio ao amado, quando a narradora na primeira página do texto enfatiza: A paixão é um dom e nos privilegia - e eu te amo porque tua alma é claricíclica e és paixão... (p.13) ${ }^{1}$.
1 VILELA, Arriete. Fantasia e avesso. Maceió: Secretaria de Cultura, 1986. As demais citações são dessa edição e aparecerão referenciadas no corpo do trabalho, indicadas apenas pelo número da página. 
As metáforas da interioridade são construídas ao longo do texto, proliferando na escrita como um convite a respirar em uníssono com a personagem que fala sua experiência amorosa na narrativa. Assim, através de uma relação quase antropofágica, o amado é "devorado", desejado e presentificado pela palavra poética, representação e liberdade do prazer que se pretende revelado: "Amar-te é tocar na força viva do prazer, ferida majestosa feito gema amarela" (p.31).

Arriete põe em xeque o que afinal no amor é legítimo ou ilegítimo, sagrado ou profano, denunciando que o erótico tem uma lógica própria que o rege. $\mathrm{O}$ desejo, a vontade, o prazer e o recato perdem os seus valores absolutos e passam a conviver numa mesma dimensão, fundindo impressões e valores que norteiam, na narrativa, a concepção de desejo expressa no texto: a primazia do amor. Com essa primazia o eu-lírico revela "Enfim: eu só sei amar quando o meu coração singulariza o amor no meio de quaisquer outros sentimentos" (p.38).

O discurso amoroso nesse livro é, então, um exercício poético que impulsiona a narradora-personagem a uma verdade necessária à compreensão de si mesma como ser sexual, e da experiência erótica no seu sentido mais amplo, chegando a ser difícil determinar as fronteiras entre o desejo e a interdição, entre a procura e a falta, o profano e o sagrado:

Sabes que distorço passado e futuro para que apenas tu sejas incluído na breve história que sou, pois amar-te é cumular-me de úmidas carícias que flutuam no teu corpo de brilho suado (p.66).

A segunda questão que se observa na leitura de Fantasia e avesso é a relação da linguagem poética com o desejo, revelando que, nessa obra, ambos se representam. Com a originalidade desse discurso, a personagemnarradora transformou o próprio erotismo em discurso poético, fazendo da palavra amorosa a representação e o centro da ordem universal da sexualidade. A paixão pela palavra integra-a ao outro - o amado -, fazendo-se carne, 
preenchimento da falta, tentativa de completude, prazer e gozo, despojando-se do caráter de erotismo torturado:

Por isso te quero tanto e sempre. Por isso te amo nas tardes vazias, os nossos olhos cervejados de alegria. Por isso divido contigo essa intensa paixão clandestina. Etcétera e tal (p.66).

Observa-se que a narradora visualiza um corpo e torna-o verbal, ou seja, a palavra deixa de significar e passa a ser o próprio objeto do desejo:

A palavra é carne selvagem e é bom provála nas garras bêbadas dos meus avessos. Teu corpo é palavra nunca decifrada, e é urgência -então te colho na teia da flor voraz, e a minha fantasia mergulha no teu cheiro secreto (p. 66 - grifo meu).

As metáforas do amor, desejo e prazer eróticos fizeram aflorar os elementos da sexualidade reprimida, que encontra no poético sua forma de liberação: "a palavra é carne e o corpo é palavra". Com esse jogo linguístico/ erótico vemos que, na escritura, erotismo é fantasia, é palavra, é avesso, é o fio da meada que se rompe e se reconstrói a cada nova narrativa: "A palavra boiando dentro de mim, energizando a minha carne: borboleta amarela rondando a flor ardente, um grande salto dentro da noite (p.32)".

Sendo a literatura um produto cultural, é fácil entendê-la como o lugar das grandes revelações, porque nela o desejo e os interditos - morais, sexuais, políticos, filosóficos, religiosos - sempre expuseram suas necessidades de revelação. Nesse sentido, a literatura é uma forma de representação metafórica do desejo, o que vem ratificar a proposta arrietiana de que a escrita é uma manifestação de um desejo, um preenchimento da falta e uma necessidade em si mesma.

Ao criar para si uma casa de palavras, a narradorapersonagem de Fantasia e avesso constrói uma linguagem voltada para si mesma (linguagem) como em um círculo de espelhos, o que faz com que o tema principal ou o 
sentido motivador do texto poético seja a própria poesia. Transgressora, a palavra vive "desafiando a teia lógica das coisas (p. 31)"

Eis a razão por que, em diversos momentos da narrativa, encontram-se definidas as concepções de amor e poesia que, repetidas vezes, se confundem no texto.

Nele, a palavra, representando o objeto substitutivo ou o objeto da falta, na concepção de Platão (1972) sobre o amor possui um lugar de destaque, não apenas pelo fato de ela se constituir em uma expressão da sexualidade, mas também por ser entendido o discurso amoroso como "vôo de metáforas" - no dizer de Júlia Kristeva (1987) -, fazendo de Fantasia e avesso a representação textual dessa metáfora: "A palavra, amor: uma emoção toda exposta à claridade do sol (p. 38)".

Assim, a linguagem, representando o ausente, é considerada como uma realização erótica e, também por funcionar como metar $\neg$ representação (representação da representação), estabelece, enquanto escrita amorosa, seus contornos sem limites: "De novo a palavra: mergulho e fôlego, um desafio (p. 19)".

Sendo a palavra o sujeito e objeto do discurso, ela é o desafio que constrói a narrativa e, assim sendo, a narradora prepara, em nível da linguagem, a passagem de Eros em busca da sua outridade, que acontece na relação escritura/desejo.

Esse livro se constitui, portanto, em uma metáfora do desejo e da fantasia, já que toda a narrativa é um deslocamento do desejo para a palavra, ou da palavra para o desejo, visto que a palavra é em si mesma o próprio desejo manifesto em fantasia: "A fantasia, amor. $\mathrm{O}$ avesso dos fatos, a realidade fibrosa, a palavra à espera (p.13)”.

Paulo Leminski (1987) afirma que "o poeta é aquele que deglute a palavra como objeto sexual mesmo, como objeto erótico (p.74)". Essa satisfação erótica que acontece na manifestação da palavra literária é claramente observada em todas as narrativas poéticas da coletânea: "A palavra me seduz, é corpo bonito dançando sobre a minha pele de pêlos eriçados de paixão (p. 54)".

Leminski apresenta, ainda, importantes observações sobre a relação do poeta com a linguagem. 
Ele considera que poesia é sobretudo "paixão pela linguagem", levando em consideração o seu caráter substantivo. Salienta a relação dúbia do poeta com a linguagem, o que ele chama de "transa apaixonada" e como tal apresenta duas faces antagônicas. Em um momento percebe-se entre o poeta e a linguagem uma relação masoquista da segunda para com o primeiro, ou seja, a palavra exerce um controle, uma violência, um avessamento no inconsciente reprimido do artista, fazendo do poeta vítima da própria linguagem, como também acontece com a narradora e a palavra em Fantasia e avesso: "A palavra, amor, é mais poderosa que a minha fantasia e mais cruel que os meus avessos (p.54).

Mais adiante, mantendo essa mesma relação de prisioneira da palavra, volta a enfatizar: "A palavra, pássaro tirano, lâmina afiada que sobrevive a si mesma (p.65)”.

Em outras circunstâncias, a relação se inverte. $\mathrm{O}$ poeta é sádico, é o algoz da palavra. É ele que a aprisiona, metamorfoseia e transgride os seus sentidos primeiros, acorrentando-a numa escritura. "Lacro a palavra (p.60)", diz a enamorada.

Em face dessa dupla relação (prisioneira e algoz), a palavra tem, na narrativa, semelhantemente ao amor, momentos distintos na mesma efabulação. Tanto é assim que:

A palavra às vezes é suave como uma flor noturna; às vezes me lanha e eu me contorço de dor e de desejo. Porque a minha paixão é impulsiva e tragicamente ardorosa (p.39).

Nota-se, ainda, no discurso, que Arriete constrói sua narrativa poética, estabelecendo a relação da palavra com o desejo, semelhantemente com a proposta de George Bataille (1987) a respeito do erotismo, no sentido de que, embora o erótico seja resultante de duas forças antagônicas - vida e morte -, elas são complementares. É assim que acontece, na narrativa, o jogo entre a palavra e o avesso, a fantasia e a palavra, o desejo e a escritura, o profano e o sagrado: "Mas estou sempre em duelo com a palavra. Por isso agora, amor, deixa-me estar quieta à sombra da eternidade (p.54)". 
Ao pretender se imortalizar através da obra literária - deixa-me estar quieta à sombra da eternidade -, a narradora entende que o erótico, assim como a arte, não se propõe a eliminar a morte, mas a transcendê-la, como ratifica Bataille.

Assim, além da fala amorosa bastante explícita no texto, o diálogo entre narradora e narrativa é, sem dúvida, também um diálogo erótico. Em Fantasia e avesso a escrita representa o desejo de, a palavra asfixiando-se na palavra (p. 26), construir um discurso que pretende, pelo imaginário poético, reclamar pela falta (desejo) e promover a fusão com o outro (erotismo), rompendo pela palavra a descontinuidade biológica dos seres. Aprisionar ou fundir o desejo em uma escritura é uma forma erótica de relacionar-se com essa mesma escritura: "A palavra, amor: uma face não revelada, uma natureza desconhecida, uma exterioridade (p.44)".

Nessa perspectiva de erotização da palavra, as metáforas contidas em Fantasia e avesso revelam o caráter mais profundo e contraditório do amor: a infinitude da sua realização. Essa infinitude é de realização erótica, cujo sentido está na aspiração poética. Como a aspiração poéticoerótica é imponderável, é palavra, é fantasia e é avesso, a sua realização última e plena é a mais controvertida aspiração do ser humano, incompatível com qualquer limite, condenada à sua própria infinitude. Assim, nessa fantasia avessada o discurso de Arriete tem a marca da falta, do desejo, da interdição, da marginalização, do fio perdido, mas, ao mesmo tempo, retomado, concluso e inconcluso, possibilidade e impossibilidade de representação erótica:

A palavra: magia e milagre, macio cetim no oco da minha alma. A palavra asfixiando-se na palavra que tu me deste e que era de vidro e se quebrou. A fantasia do reino de muitos avessos e de poucas palavras verdadeiras (p.26).

O título do livro - Fantasia e avesso - e das dez narrativas que compõem a obra (o título se repete nos relatos numerados em romanos de $\mathrm{I}$ a $\mathrm{X}$ ) joga com essa noção de erotismo/palavra/escritura. O erotismo é, no imaginário da fantasia, uma representação simbolizada 
em palavras, razão por que, no texto, as dez narrativas que compõem o livro são, na verdade, um só texto, que se articula de tal forma que a história contada é uma só, sem princípio, meio ou fim, constituindo as dez narrativas em microrrelatos dentro de um maior. Essa proposta poético-erótica de se prolongar ou permanecer unida por um fio revela mais uma vez a certeza de que o desejo se movimenta incessantemente de um objeto para outro. Têm-se, portanto, tantos fios rompidos quantas retomadas forem necessários para a representação do amor. Citam-se alguns trechos a título de exemplificação:

Término de "Fantasia e avesso II";

Ah, amor: fantasia e avesso. O fio da meada perdido... (p.21);

Início de "fantasia e avesso III";

... e retomado. Noutros termos, bem sabemos (p.25).

Percebe-se que o desejo metafórico que perpassa a narrativa é redistribuído em parcelas expressivas que constituem o conjunto das dez narrativas eróticas que formam o livro. Por isso, cada narrativa (de I a X) é, em essência, uma parte, uma parcela metonímica da metáfora central.

Daí, a inexistência de nomes, rostos, espaços físico-geográficos ou episódios sequenciados. Só existe a representação de um conteúdo imaginado a dois: o eu o tu, e, através do diálogo desses dois seres e da revelação, no discurso, da experiência erótica imaginada, é que se reconhece a unidade temática do livro: uma proposta de amor: "Tu, amor: a força viva do prazer (p. 65)".

Conclui-se com a leitura da obra que o prazer e o erótico revelam no texto suas idiossincrasias: infinito e efêmero; promíscuo e puro; sereno e tempestuoso, clandestino e abençoado. Essas metáforas se confundem na própria urdidura do texto, traduzindo as diversas concepções atribuídas a esse sentimento na obra.

Fantasia e avesso é uma prosa poética intimista, catártica na liberação das emoções, fazendo desse texto um poema narrativo que confunde intencionalmente o prazer, o amor, a fantasia, o erótico e o avesso revelado em palavras. 


\section{Referências}

BATAILLE, George. O erotismo. Porto Alegre: L\&PM, 1987.

KRISTEVA, Júlia. No principio era o amor: psicanálise e fé. São Paulo: Brasiliense, 1987.

. Histórias de amor. Rio de Janeiro: Paz e Terra, 1988.

LEMINSKI, Paulo. "Poesia: a paixão da linguagem". ln:

CARDOSO, Sérgio et alii. Os sentidos da paixão. São Paulo:

Companhia das Letras, 1987.

PLATÃO. O banquete. In: . Diálogos. São Paulo: Abril Cultural, 1972. (Os Pensadores).

VILELA, Arriete. Fantasia e avesso. Maceió: Secretaria de Cultura/Sergasa, 1986. 